\title{
Molecular Docking Senyawa Vitexin, Ursolic Acid dan Flavonol dalam Tumbuhan Binahong (Andredera Cordifolia (Ten.) Steenis) yang Berpotensi sebagai Penghambat Pertumbuhan COVID-19
}

\author{
Sensea R. Rambitan, ${ }^{1}$ Aaltje Manampiring, ${ }^{2}$ Fatimawali, ${ }^{2}$ Billy J. Kepel, ${ }^{2}$ \\ Fona Budiarso, ${ }^{2}$ Widdhi Bodhi ${ }^{2}$
}

\author{
${ }^{1}$ Program Studi Pendidikan Dokter Fakultas Kedokteran Universitas Sam Ratulangi \\ Manado, Indonesia \\ ${ }^{2}$ Bagian Kimia Fakultas Kedokteran Universitas Sam Ratulangi Manado, Indonesia \\ Email: sensearambitan@gmail.com
}

\begin{abstract}
Currently, there is no specific treatment for all the COVID-19 patients the procedures that can be done are just a symptomatic and oxygen therapy, Therefore all the people around the world have try to avoid this infection by consuming the potensial plants that can boost our body immunity like Binahong. This study was an in silico experimental. The finale result is the binding affinity score from each compound, for vitexin's binding affinity score is $-8.0 \mathrm{kcal} / \mathrm{mol}$, ursolic acid $-7.6 \mathrm{kcal} / \mathrm{mol}$ and flavonol $-7.8 \mathrm{kcal} / \mathrm{mol}$. The finale result of this procedure also obtained all the amino acid residues that works on the active site of receptor 6LU7 as a main protase of COVID-19, namely THR24, LEU27, HIS41, THR45, SER46, MET49, PHE140, LEU141, ASN142, GLY143, SER144, CYS145, HIS163, MET165, GLU166 and HIS172. In conclusion, the binding affinity of vitexin, ursolic acid and flavonol are higher than remdesivir. Vitexin, ursolic acid and flavonol have a several similar bonds, particularly the van der waals bond and hydrogen bond.
\end{abstract}

Keywords: Molecular docking, COVID-19, binahong, flavonoid

\begin{abstract}
Abstrak: Saat ini belum tersedia rekomendasi tatalaksana khusus bagi pasien COVID-19, termasuk antivirus atau vaksin dan tata laksana yang dapat dilakukan adalah terapi simtomatik dan karena itulah, masyarakat dunia mencoba banyak cara agar menghindari infeksi virus ini dengan mengolah dan mengonsumsi tumbuhan yang dinilai berpotensi dalam meningkatkan imunitas tubuh seperti tumbuhan Binahong. Penelitian ini menggunakan metode penelitian in silico. Pada hasil akhir penelitian diperoleh nilai binding affinity dari ketiga senyawa yaitu senyawa vitexin $-8.0 \mathrm{kcal} / \mathrm{mol}$, Ursolic Acid $-7.6 \mathrm{kcal} / \mathrm{mol}$ dan Flavonol $-7.8 \mathrm{kcal} / \mathrm{mol}$. Diperoleh data mengenai residu asam amino yang bekerja pada sisi aktif reseptor 6LU7 sebagai main protase COVID-19 yaitu THR24, LEU27, HIS41, THR45, SER46, MET49, PHE140, LEU141, ASN142, GLY143, SER144, CYS145, HIS163, MET165, GLU166, dan HIS172. Sebagai simpulan, binding affinity dari senyawa vitexin, ursolic acid dari flavonol lebih tinggi dari nilai binding affinity remdesivir. Senyawa vitexin, ursolic acid dan flavonol memiliki beberapa jenis ikatan yang sama termasuk ikatan van der Waals dan ikatan hydrogen.
\end{abstract}

Kata Kunci: Molecular docking, COVID-19, binahong, flavonoid

\section{PENDAHULUAN}

Kondisi dunia saat ini sedang dihebohkan oleh pandemi COVID-19 yang mengancam kesehatan seluruh individu. Awalnya, penyakit ini dinamakan sementara sebagai 2019 novel coronavirus (2019nCoV), kemudian WHO mengumumkan nama baru pada 11 Februari 2020 yaitu Corona Virus Disease (COVID-19) yang disebabkan oleh virus Severe Acute Respiratory Syndrome Coronavirus-2 (SARS-CoV-2). ' Coronavirus yang menjadi etiologi COVID-19 termasuk dalam genus betacoronavirus. ${ }^{2}$ Struktur genom 
virus ini memiliki pola seperti coronavirus pada umumnya. Sekuens SARS-CoV-2 memiliki kemiripan dengan coronavirus yang diisolasi pada kelelawar, sehingga muncul hipotesis bahwa SARS-CoV-2 berasal dari kelelawar yang kemudian bermutasi dan menginfeksi manusia. Saat ini, penyebaran SARS-CoV-2 dari manusia ke manusia menjadi sumber transmisi utama sehingga penyebaran menjadi lebih agresif. Penularan ini terjadi umumnya melalui droplet dan kontak dengan virus kemudian virus dapat masuk ke dalam mukosa yang terbuka. ${ }^{1}$

COVID-19 pertama dilaporkan di Indonesia pada tanggal 2 Maret 2020 sejumlah 2 kasus. Data 31 Maret 2020 menunjukkan kasus yang terkonfirmasi berjumlah 1.528 kasus dan 136 kasus kematian. Tingkat mortalitas COVID-19 di Indonesia sebesar 8,9\%, angka ini merupakan yang tertinggi di Asia Tenggara. ${ }^{1}$ Total kasus konfirmasi COVID19 global per tanggal 16 September 2020 adalah 29.444.198 kasus dengan 931.321 kematian (CFR 3,2\%) di 215 Negara Terjangkit dan 180 Negara Transmisi local. ${ }^{3}$ Di Indonesia, total kasus Konfirmasi per tanggal 16 September 2020 adalah 228.993 kasus dengan kematian 9.100 (CFR 4,0). ${ }^{4}$ Saat ini belum tersedia rekomendasi tata laksana khusus bagi pasien COVID-19, termasuk antivirus atau vaksin. Tata laksana yang dapat dilakukan adalah terapi simtomatik dan oksigen. ${ }^{1}$ Karena itulah, masyarakat dunia mencoba banyak cara agar menghindari infeksi virus ini. Salah satu cara yang dilakukan adalah menjaga imun tubuh dengan mengolah dan mengonsumsi tanaman yang dinilai berpotensi dalam meningkatkan imunitas tubuh sehingga meminimalizir kemungkinan terinfeksi virus ini.

Tanaman Binahong (Andredera Cordifolia (Ten.) Steenis) adalah salah satu tanaman yang secara empiris digunakan untuk mengobati berbagai penyakit oleh masyarakat Sulawesi Utara. ${ }^{5}$ Tanaman ini dikenal dengan sebutan Madeira Vine dipercaya memiliki kandungan antioksidan tinggi dan antivirus. ${ }^{5}$ Aktifitas farmakologi ekstrak etanol Binahong yang ditunjukkan oleh mekanisme kerja berdasarkan kemampuan senyawa flavonoid untuk menimbulkan aktivitas biologis. Penelitian farmakologi terhadap senyawa flavonoid menunjukkan bahwa beberapa senyawa golongan flavonoid memperlihatkan aktivitas seperti antifungi, diuretik, antihistamin, antihipertensi, insektisida, bakterisida, antivirus dan menghambat kerja enzim. ${ }^{5}$

Berdasarkan latar belakang diatas, saat ini peneliti tertarik dan memiliki minat untuk meneliti tentang senyawa-senyawa aktif flavonoid yang terkandung dalam tumbuhan Binahong (Andredera Cordifolia (Ten.) Steenis) yang berpotensi sebagai penghambat pertumbuhan COVID-19.

\section{METODE PENELITIAN}

Penelitian ini dilakukan pada bulan September - Desember 2020. Molecular Docking senyawa-senyawa kimia dalam tumbuhan Binahong (Andredera Cordifolia (Ten.) Steenis) dilakukan di Bagian Kimia, Fakultas Kedokteran Universitas Sam Ratulangi Manado. Sampel penelitian berupa ligand dari senyawa-senyawa golongan Flavonoid yang terdapat pada tanaman Binahong (Anredera cordifolia (Ten.) Steenis) diambil dari website PubChem (https://pubchem.ncbi.nlm.nih. gov/) yaitu; vitexin, ursolic acid, and flavonol. Dengan dilakukannya simulasi docking antara ligan vitexin, ursolic acid, dan flavonol yang merupakan senyawa flavonoid yang terkandung dalam tanaman Binahong (Anredera cordifolia (Ten.) Steenis) terhadap reseptor dari coronavirus, diharapkan terbentuknya reaksi yang kuat dari senyawa-senyawa aktif tumbuhan Binahong sebagai penghambat pertumbuhan COVID-19.

Alat yang digunakan dalam penelitian ini berupa computer ASUS Vivobook 14 Intel ${ }^{\circledR}$ Inside Core i3 dengan system operasi Windows 10, Autodock tools, Autodock Vina, Discovery Studio, Open Babel, Protein Data Bank www.rscb.org dan ligan pada website PubChem www.pubchem.ncbi.nlm.nih.gov/ . 
Bahan yang digunakan yaitu struktur 3D ligan Vitexin, Ursolic Acid, dan Flavonol yang merupakan senyawa Flavonoid dalam tanaman Binahong (Anredera cordifolia (Ten.) Steenis) dan main protase COVID-19 (6LU7).

Senyawa-senyawa Flavonoid dalam tanaman Binahong (Anredera cordifolia (Ten.) Steenis) yang akan dijadikan ligan diperoleh melalui situs website PubChem dan didownload dengan format SDF 3D. Kemudian buka aplikasi open babel untuk format SDF ke PDB. Reseptor COVID-19 diambil dari situs website Protein Data Bank (PDB) yang kemudian didownload dengan format PDB. Lalu buka aplikasi Discovery Studio visualisasi untuk membersihkan reseptor yang masih kotor.

Pertama, klik menu Script » Selection »Select water molekul » Delete. Kedua, klik menu Script » Selection » Select ligan »Delete. Jika reseptor sudah bersih, klik menu file dan save reseptor dalam format PDB.

Proses molecular docking menggunakan aplikasi Autodock tools dan Autodock Vina. Hasil akhir struktur reseptor dan ligan yang sudah bersih disimpan dalam satu folder yang sama. Proses molecular docking akan menggunakan autodock tools terlebih dahulu untuk mempersiapkan reseptor dengan tahapan sebagai berikut: Buka aplikasi autodock tools kemudian klik read moleculer pada menu file dan pilih reseptor yang akan di docking. Reseptor yang sudah sudah ada ditambahkan dengan hydrogen dan centang pada pilihan all hydrogen, method no bondorder, yes renumber atom in clude new hydrogen, dan klik OK. Setelah reseptor sudah ditambah dengan hydrogen, klik grid makromolekuler kemudian klik choose, klik reseptor dan terakhir select molekul, kemudian disimpan dalam format PDBQT. Selanjutnya untuk persiapan ligan, mengikuti tahapan selanjutnya.

Selanjutnya jika ligan sudah keluar dilayar kerja, klik torsion free untuk mengatur number of torsion pada ligan, selanjutnya simpan ligan dalam format PDBQT.
Langkah berikutnya yaitu mempersiapkan binding site atau tempat dimana ligan akan menambatkan diri pada reseptor. Langkah-langkah sebagi berikut: pilih reseptor dengan format PDBQT, masukan asam amino dari main protease COVID-19 yang diperoleh dari Computed Atlas of Surface Topography of proteins dengan cara klik reseptor kemudian klik chain A. Kemudian klik grid box pada menu grid, selanjutnya sesuaikan number of point pada sumbu x (merah), y (hijau), z (biru), center $\mathrm{x}$ (merah), y (hijau), $\mathrm{z}$ (biru), spacing (angstrom) hingga seluruh asam amino pada reseptor berada pada binding site.

Selanjutnya buka aplikasi Notepad dan masukkan data seperti reseptor, ligan, center $\mathrm{x}$, center $\mathrm{y}$, center $\mathrm{z}$, size $\mathrm{x}$, size $\mathrm{y}$, size $\mathrm{z}$ dan keakuratan, kemudian save di folder yang telah dibuat. Selanjutnya masukan aplikasi Autodock vina yang terdiri dari vina, vina split, dan vina license pada folder yang telah dibuat, kemudian buka aplikasi Command prompt dan masukan format (contoh: C:luserl Costumer> D:\ cd vina..), lalu masukkan rumus untuk untuk perhitungan dalam command prompt: Config conf.txt - log log.txt maka akan muncul hasil binding affinity dari ligan yang diteliti. Setelah itu gunakan vina split untuk memisahkan hasil dari ligan satu per satu dengan menggunakan rumus D:|vina>vina_split -input out.pdbqt. Tahap terakhir yaitu vusialisasi dengan cara drag reseptor reseptor dan out ligan 1 di Discovery studio visualisasi kemudian dilihat hasilnya dalam bentuk 2D dan 3D.

\section{HASIL PENELITIAN}

Penelitian ini dilakukan dengan metode molecular docking dimana metode ini bertujuan untuk melihat ikatan kimia antara ligan dan reseptor serta mengetahui nilai binding affinity dari ikatan yang akan terbentuk. Sebelum dilakukan proses docking, perlu dilakukan pengecekan kembali sifat-sifat ligan yang akan di docking berdasarkan Aturan Lipinski. Aturan Lipinski menegaskan tentang sifat molekuler dan farmakokinetik obat bagi 
tubuh manusia. Aturan Lipinski dapat menentukan sifat fisikokimia ligan untuk menentukan karakter hidrofobik/hidrofilik suatu senyawa untuk melalui membran sel oleh difusi pasif. ${ }^{6}$

Tabel 1. Lipinski Rule of Five

\begin{tabular}{|c|c|c|c|c|c|}
\hline & & & & $H-$ & \\
\hline No.Ligands & $\begin{array}{l}\text { Molecular } \\
\text { Formula }\end{array}$ & $\begin{array}{c}\text { Weight } \\
(<500 \\
\text { Da })\end{array}$ & $\begin{array}{l}\log 1 \\
(<5\end{array}$ & $\begin{array}{c}\text { Bond } \\
\text { Donor } \\
(<5) \\
\end{array}$ & $\begin{array}{l}\text { Accepto } \\
(<10)\end{array}$ \\
\hline 1. Vitexin & $\mathrm{C}_{21} \mathrm{H}_{20} \mathrm{O}_{10}$ & $\begin{array}{l}432.4 \\
\mathrm{~g} / \mathrm{mol}\end{array}$ & 0.2 & 5 & 10 \\
\hline $\begin{array}{l}\text { Ursolic } \\
\text { Acid }\end{array}$ & $\mathrm{C}_{30} \mathrm{H}_{48} \mathrm{O}_{3}$ & $\begin{array}{l}456.7 \\
\mathrm{~g} / \mathrm{mol}\end{array}$ & 7.3 & 2 & 3 \\
\hline 3. Flavonc & $1 \mathrm{C}_{27} \mathrm{H}_{30} \mathrm{O}$ & $\begin{array}{l}546.5 \\
g / m o l\end{array}$ & -0.4 & 6 & 12 \\
\hline
\end{tabular}

Tabel 2. Binding Affinity vitexin, ursolic acid dan flavonol

\begin{tabular}{ccc}
\hline No. & Ligands & Binding Affinity \\
\hline 1. & Vitexin & $-8.0 \mathrm{kcal} / \mathrm{mol}$ \\
2. & Ursolic Acid & $-7.6 \mathrm{kcal} / \mathrm{mol}$ \\
3. & Flavonol & $-7.8 \mathrm{kcal} / \mathrm{mol}$ \\
\hline
\end{tabular}

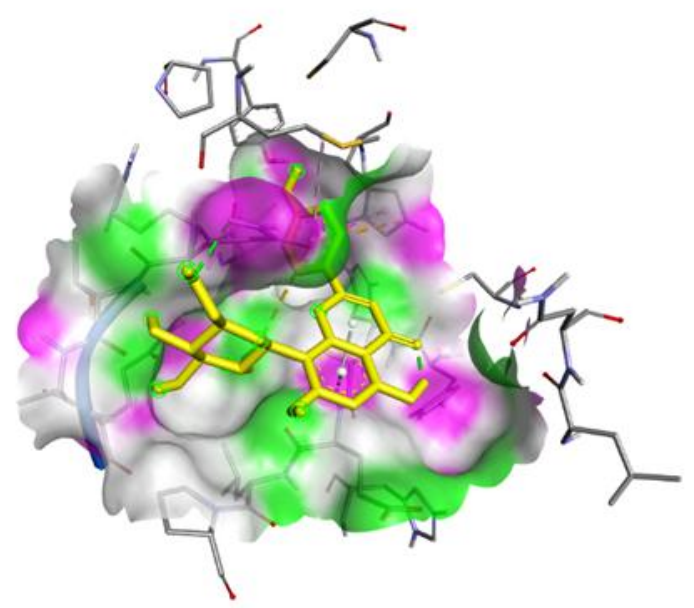

Gambar 1. Visualisasi 3D hasil molecular docking ligand vitexin dengan reseptor 6LU7

Berdasarkan aturan Lipinski yang tercantum pada tabel 1 , senyawa vitexin memiliki berat molekul $432.4 \mathrm{~g} / \mathrm{mol}, \log P$ 0.2, H-bond donor 5, H-bond acceptor 10 dan hal ini menunjukkan bahwa senyawa vitexin memenuhi kriteria dari aturan Lipinski, sedangkan senyawa ursolic acid dengan berat molekul $456.7 \mathrm{~g} / \mathrm{mol}, \log P$ 7.3, H-bond donor 2, H-bond acceptor 3 dan senyawa Flavonol dengan berat molekul $546.5 \mathrm{~g} / \mathrm{mol}, \log P$-0.4, H-bond donor 6, H-bond acceptor 12 tidak memenuhi kriteria aturan Lipinski.

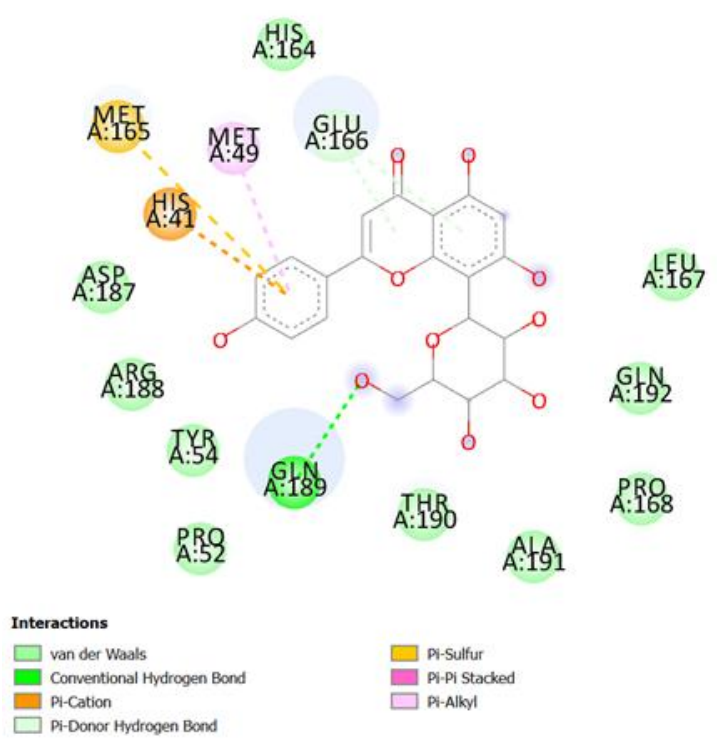

Gambar 2. Visualisasi 2D hasil molecular docking ligand vitexin dengan reseptor 6LU7

Setelah dilakukan molecular docking terhadap 3 senyawa flavonoid dalam tumbuhan Binahong yaitu vitexin, ursolic acid dan flavonol dengan main protase COVID-19 (6LU7), didapatkan nilai binding affinity dari setiap ligan. Parameter kestabilan hasil penelitian yaitu nilai binding affinity yang ditentukan berdasarkan nilai tertinggi yang muncul dimana semakin negatif nilai $\Delta G$ (Energi bebas Gibbs) menunjukan tingkat kestabilan yang baik antara ligan dan reseptor, sehingga ikatan yang terbentuk akan semakin kuat. Pada hasil akhir simulasi docking senyawa-senyawa flavonoid dalam tumbuhan Binahong, diambil nilai binding affinity yang tertinggi atau nilai yang paling negatif karena memiliki interaksi paling kuat. Seperti yang tercantum dalam Tabel 2, senyawa vitexin memperoleh hasil akhir $-8.0 \mathrm{kcal} / \mathrm{mol}$, Ursolic Acid $-7.6 \mathrm{kcal} / \mathrm{mol}$ dan Flavonol $7.8 \mathrm{kcal} / \mathrm{mol}$.

Interaksi antara ligan vitexin dan 
reseptor 6LU7 dapat dilihat diaplikasi discovery studio dalam bentuk 3D dan 2D. Pada visualisasi senyawa vitexin dengan 6LU7 dapat dilihat adanya beberapa ikatan yang terbentuk sebagai hasil interaksi ligand-reseptor, yaitu ikatan van der Waals, conventional hydrogen bond, pi-cation, pidonor hydrogen, pi-sulfur, pi-pi stacked dan pi-alkyl. Pada visualisasi senyawa ursolic acid dengan 6LU7 dapat dilihat adanya beberapa ikatan yang terbentuk sebagai hasil interaksi ligand-reseptor, yaitu ikatan van der Waals, conventional hydrogen bond, carbon hydrogen bond dan unfavorable donor-donor. Pada visualisasi senyawa flavonol dengan 6LU7 dapat dilihat adanya beberapa ikatan juga yang terbentuk sebagai hasil interaksi ligandreseptor, yaitu ikatan van der Waals, conventional hydrogen bond, carbon hydrogen bond, unfavorable acceptoracceptor, unfavorable donor-donor, pication, pi-donor hydrogen bond, pi-sulfur dan pi-alkyl.

\section{BAHASAN}

Hasil penelitian molecular docking senyawa-senyawa kimia golongan flavonoid dalam tumbuhan Binahong berupa nilai binding affinity, ikatan kimia yang terbentuk serta residu asam amino. Berdasarkan hasil visualisasi dalam bentuk 2D, diperoleh beberapa ikatan yang terbentuk dari masing-masing senyawa yaitu ikatan van der Waals, conventional hydrogen bond, carbon hydrogen bond, unfavorable acceptor-acceptor, unfavorable donor-donor, pi-cation, pi-donor hydrogen bond, pi-pi stacked, pi-sulfur dan pi-alkyl.

Pada senyawa vitexin, ikatan van der Waals terbentuk pada asam amino residu HIS164, ASP187, ARG188, TYR54, PRO52, THR190, ALA191, PRO168, GLN192 dan LEU167. Ikatan hydrogen terbentuk pada asam amino residu GLN189 dan GLU166. Ikatan sulfur terbentuk pada residu MET165. Ikatan $\mathrm{Pi}$ - cation terbentuk pada residu HIS41. Ikatan alkyl terbentuk pada MET49. Pada senyawa ursolic acid, ikatan van der Waals terbentuk pada asam amino residu MET49, THR25,
GLY143, HIS41, MET165, HIS164, GLU166, GLN189, PRO168 dan THR190. Ikatan hydrogen terbentuk pada residu asam amino LEU141, CYS145 dan ASN142. Ikatan Unfavorable donor-donor terbentuk pada residu SER144. Pada senyawa flavonol, ikatan van der Waals terbentuk pada asam amino residu TYR45, ASP187, ARG188, HIS164, ASN142, LEU27 dan GLN189. Ikatan hydrogen terbentuk pada residu GLY143, SER144, CYS145, GLU166 dan MET165. Ikatan pication terbentuk pada residu HIS41. Ikatan alkyl terbentuk pada residu MET49. Ikatan unfavorable acceptor-acceptor dan unfavorable donor-donor terbentuk pada residu HIS163 dan LEU141.

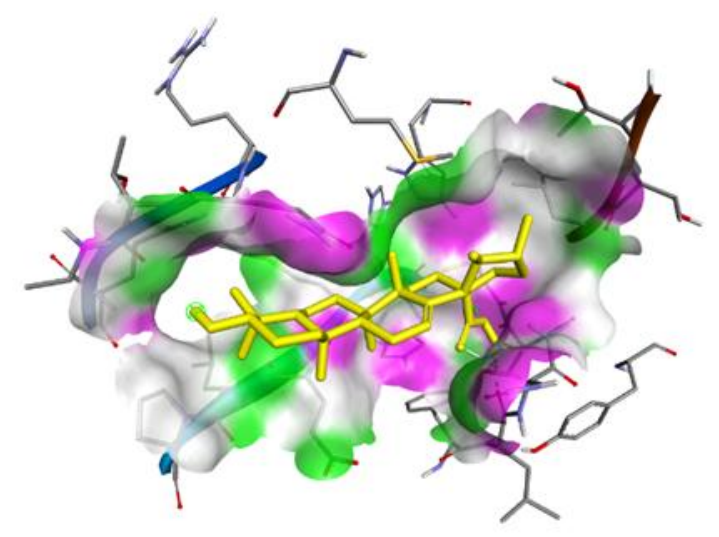

Gambar 3. Visualisasi 3D hasil molecular docking ligand ursolic acid dengan reseptor 6LU7

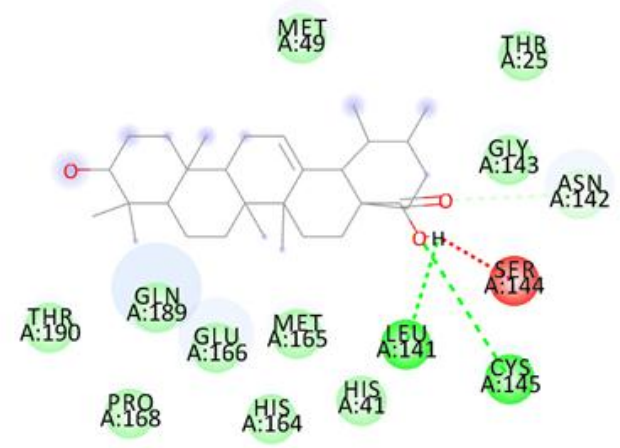

Interactions
$\square$ van der Waals

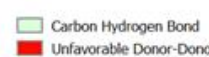

Gambar 4. Visualisasi 2D hasil molecular docking ligand ursolic acid dengan reseptor 6LU7 
Pada computed atlas of surface diperoleh data mengenai residu asam amino yang bekerja pada sisi aktif reseptor 6LU7 sebagai main protase COVID-19 yaitu THR24, LEU27, HIS41, THR45, SER46, MET49, PHE140, LEU141, ASN142, GLY143， SER144， CYS145， HIS163, MET165, GLU166, dan HIS172.

Asam amino dari senyawa vitexin yang sesuai dengan residu asam amino dan bekerja pada sisi aktif reseptor 6LU7 yaitu HIS41, MET49, MET165, dan GLU166. Untuk senyawa ursolic acid, residu asam amino yang sesuai dengan asam amino dan bekerja pada sisi aktif reseptor 6LU7 yaitu MET45, GLY143, ASN142, SER144, HIS41, MET165, GLU166, CSY145 dan LEU141. Pada senyawa flavonol, residu asam amino yang sesuai dengan residu asam amino reseptor 6LU7 yaitu HIS163, ASN142, LEU141, MET165, HIS41, GLU166, LEU27, MET49, CYS145, SER144 dan GLY143.

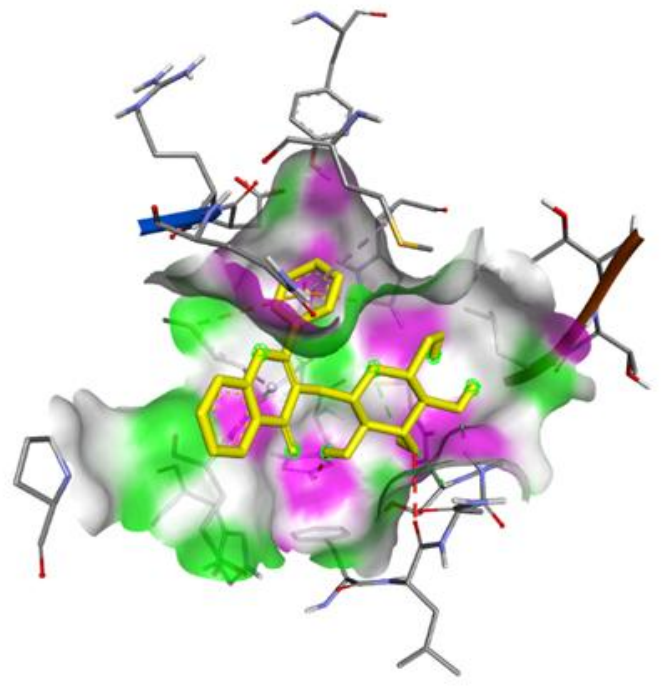

Gambar 5. Visualisasi 3D hasil molecular docking ligand flavonol dengan reseptor 6LU7

Pada kontrol positif penelitian ini digunakan ligand dari obat COVID-19 yaitu remdesivir sebagai pembanding dengan senyawa vitexin, ursolic acid dan flavonol yang terkandung dalam tumbuhan Binahong (Andredera cordifolia (Ten.) Steenis). Setelah dilakukan molecular docking terhadap remdesivir, diperoleh hasil binding affinity yaitu $-7.3 \mathrm{kcal} / \mathrm{mol}$. Berdasarkan perbandingan nilai binding affinity antara remdesivir, vitexin, ursolic acid dan flavonol, maka diperoleh kesimpulan bahwa senyawa vitexin, ursolic acid dan flavonol memiliki nilai binding affinity yang lebih tinggi dari remdesivir.
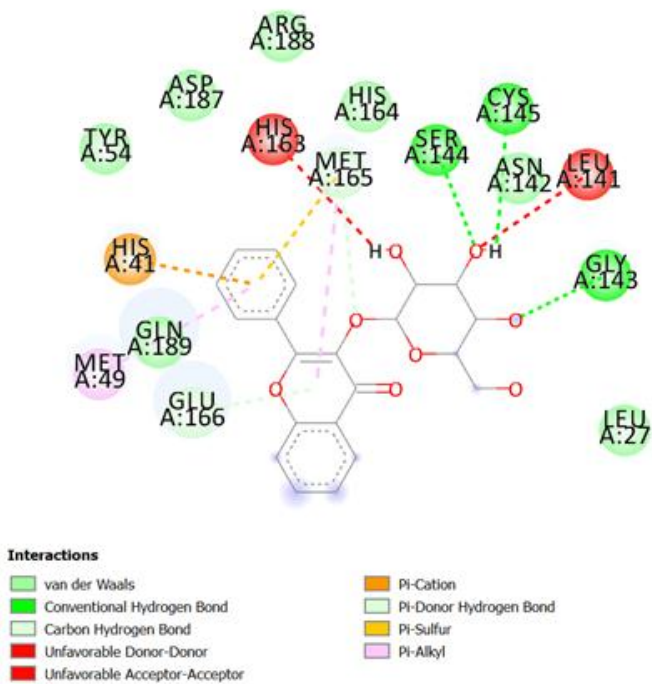

Gambar 6. Visualisasi 2D hasil molecular docking ligand flavonol dengan reseptor 6LU7

\section{SIMPULAN}

Senyawa vitexin, ursolic acid dan flavonol memiliki beberapa jenis ikatan yang sama termasuk ikatan van der Waals dan ikatan hydrogen. Dengan adanya kedua ikatan ini menandakan bahwa hasil docking dari ketiga senyawa tersebut memiliki ikatan yang kuat. Asam amino residu dari senyawa vitexin, ursolic acid dan flavonol sebagian besar sesuai dengan asam amino residu pada reseptor 6LU7 yang artinya residu asam amino dari ligand bekerja pada sisi aktif main protase COVID-19 (6LU7). Binding affinity dari senyawa vitexin, ursolic acid dari flavonol lebih tinggi dari nilai binding affinity remdesivir. Ketiga senyawa golongan flavonoid yang diteliti memiliki hasil yang baik dan berpotensi sebagai obat dalam menghambat pertumbuhan COVID-19. Namun dari ketiga senyawa tersebut senyawa vitexin memiliki hasil yang paling tinggi, kemudian diikuti oleh senyawa ursolic acid dan senyawa flavonol. 


\section{Konflik Kepentingan}

Penulis menyatakan tidak terdapat konflik kepentingan dalam studi ini.

\section{DAFTAR PUSTAKA}

1. Susilo A, Rumende CM, Pitoyo CW, SAntoso WD, Yulianti M, Herikurniawan, et al. Coronavirus Disease 2019: Tinjauan Literatur Terkini. Jurnal Penyakit Dalam Indonesia 2020;7(1): 45-67.

2. Handayani D, Hadi DR, Isbaniah F, Burhan E, Agustin H. Penyakit Virus Corona 2019. Jurnal Respirologi Indonesia 2020;40(2):119-29.

3. Situasi Terkini Perkembangan Coronavirus Disease (COVID-19) 17 September $2020 »$ Info Infeksi Emerging Kementerian Kesehatan RI. https://covid19.kemkes.go.id/situasiinfeksi-emerging/info-coronavirus/situasi-terkini-perkembangancoronavirus-disease-covid-19-17september-2020/\#.X2PZuWhKg2y.

4. Kementerian Kesehatan RI. Situasi Terkini Perkembangan (COVID-19). Kementerian Kesehatan RI 17-19, 2020.

5. Saati EA. Studi Stabilitas Ekstrak Pigmen Antosianin Bunga Mawar Rontok pada Periode Simpan Tertentu (Kajian Keragaman pH Media dan Suhu Pasteurisasi. Jurnal Gamma 2005;1(1):77-82.

6. Nursalam. Metode Penelitian Ilmu Keperawatan: Pendekatan Praktis. Edisi 5. Jakarta: Salemba Medika, 2020. 